\title{
Persiapan Dunia Kerja bagi Siswa SMKN 39 Jakarta: Edukasi Penulisan CV, Psikotes, dan Wawancara
}

\author{
Job Market Preparation for Vocational Students of SMKN 39 Jakarta: \\ CV Writing, Psychological Tests, and Interviews
}

\begin{tabular}{l|r}
\hline Rina Rahmatika ${ }^{1}$, Novika Grasiaswaty & \\
\& Sunu Bagaskara $^{\mathbf{3}}$ & Article history: \\
123 Program Studi Psikologi Fakultas Psikologi & Submitted: 23 June 2021 \\
Universitas YARSI, Jakarta, Indonesia & Accepted: 12 July 2021 \\
novika.grasiaswaty@yarsi.ac.id & Published: 21 July 2021 \\
\hline
\end{tabular}

Abstract: Vocational students feel that it is more difficult to compete for jobs after completing their education. In fact, they are expected to find it easier to get a job because they have been equipped with specific skills that are in accordance with their majors. Through the training, it is hoped that it can help vocational students to prepare themselves to compete in the job market. The method used is counseling and providing information to 27 SMKN 39 Jakarta students who will prepare for internships. Based on the statistical analysis of paired samples t-test, there was an increase of 28.89 points between before and after the participants attended the training. This shows that the training provided is effective in preparing participants to meet the job market demands.

Keywords: education; job market; vocational students; work preparation.

Abstrak: Siswa SMK merasa bahwa lebih sulit bersaing untuk mendapatkan pekerjaan setelah menyelesaikan pendidikannya. Padahal, lulusan SMK diharapkan lebih mudah mendapatkan pekerjaan dikarenakan sudah dibekali keterampilan khusus yang sesuai dengan jurusannya. Melalui kegiatan pelatihan yang dilakukan ini, diharapkan dapat membantu siswa SMK untuk mempersiapkan diri bersaing di dunia kerja. Metode yang digunakan yaitu dengan penyuluhan dan pemberian informasi pada 27 siswa SMKN 39 Jakarta yang akan bersiap untuk magang. Berdasarkan analisis statistik t-test sampel berpasangan, terdapat peningkatan sebesar 28,89 poin antara sebelum dan setelah peserta mengikuti pelatihan. Hal ini menunjukkan bahwa kegiatan pelatihan yang dilakukan efektif dalam mempersiapkan peserta memasuki dunia kerja.

Kata kunci: edukasi; lapangan kerja; persiapan kerja; siswa SMK. 


\section{Pendahuluan}

Pendidikan kejuruan merupakan suatu jenjang proses pendidikan yang diarahkan kepada anak remaja yang terampil dalam bidang pekerjaan tertentu dan siap untuk berkarir di dunia kerja (Nuryanto \& Eryandi, 2020). Bagian dari pendidikan kejuruan di Indonesia salah satunya adalah Sekolah Menengah Kejuruan (SMK). Lulusan SMK diharapkan mampu mengisi kebutuhan dunia kerja terutama pekerjaan yang membutuhkan tenaga terampil. Atas dasar tersebut, materi yang dipelajari siswa antara SMK dan SMA akan berbeda. Jika siswa SMA lebih menitikberatkan pada teori, sedangkan siswa SMK lebih banyak pada praktik yang diharapkan mampu menguasai praktik-praktik spesifik yang sesuai dengan minat dan jurusan mereka. Lulusan SMK diharapkan lebih mudah mendapatkan pekerjaan dan membuka lapangan pekerjaan sendiri. Sayangnya, seringkali harapan ini tidak tercapai di dunia nyata. Juwitaningrum (2013) menuturkan bahwa permasalahan mengenai karir lebih membebani siswa SMK dibandingkan dengan siswa SMA dikarenakan siswa SMK yang dituntut sebagai individu yang siap bekerja setelah menyelesaikan pendidikan kejuruan. Beberapa guru BK (Bimbingan Konseling) dan siswa sendiri menuturkan bagaimana mereka lebih susah bersaing untuk mendapatkan pekerjaan setelah menyelesaikan pendidikan mereka di sekolah kejuruan.

Salah satu yang dapat menjembatani permasalahan ini adalah meningkatkan kesiapan siswa dalam memasuki dunia kerja. Siswa yang menerima proses pembelajaran di sekolah dan dunia kerja diharapkan mampu menjadi tenaga kerja dengan tingkat kesiapan kerja yang tinggi (Krisnamurti, 2017). Kesiapan memasuki dunia kerja tidak hanya mengenai apakah mereka memiliki keterampilan tetapi aspek psikologis dalam proses pencarian kerja dan bekerja itu sendiri. Wagner (dalam Firdaus, 2013) mendefinisikan kesiapan kerja adalah seperangkat keterampilan dan perilaku seseorang yang dibutuhkan untuk bekerja dalam segala bentuk pekerjaan. Dalam penelitian terdahulu oleh Afriani \& Setiyani (2015) ditemukan bahwa hal yang dapat mempengaruhi kesiapan kerja adalah penguasaan soft skill. Kesuksesan seseorang dalam pekerjaan tidak hanya ditentukan oleh hard skill, melainkan ditentukan juga oleh soft skill yang menentukan seseorang mampu diterima dengan baik di lingkungan kerjanya atau tidak. Pelatihan ataupun pemberian materi kepada siswa SMK biasanya lebih pada seputar pengetahuan akan skill mereka. Tetapi, pelatihan yang biasanya diberikan kepada siswa SMK belum banyak yang mengacu pada kesiapan mereka dalam bekerja (Dharmawati, 2020; Guntoro et al., 2017).

Kuswana (2013) menyebutkan salah satu ciri seseorang yang memiliki kesiapan kerja yaitu mengetahui tentang prasyarat kerja berdasarkan dimensi pengetahuan faktual, pengetahuan konseptual, pengetahuan prosedural, dan pengetahuan yang saling terkait. Selain itu, dukungan positif dapat memberikan rasa percaya diri pada siswa yang menimbulkan kesiapan kerja siswa tersebut. Dukungan sosial dapat diartikan sebagai tindakan dari seseorang untuk orang lain dalam memberikan sebuah dukungan (Lestari \& Siswanto, 2015). Untuk itu, sebagai lulusan yang nantinya diharapkan untuk bekerja setelah menyelesaikan pendidikannya, siswa SMK perlu dukungan atau tindakan yang membantu siswa SMK mendapatkan informasi mengenai persiapan dalam proses pencarian kerja. Secara umum, metode yang biasanya digunakan untuk seleksi calon pekerja adalah melalui form aplikasi, prestasi akademik, wawancara dan kemampuan kognitif yang diukur melalui tes (Caballero et al., 2011). 


\section{Aspek-Aspek Kesiapan Kerja}

Caballero dkk (2011) melakukan studi kualitatif dan kuantitatif untuk mengetahui mengenai aspek-aspek kesiapan kerja dari perspektif calon pekerja dan pihak pengguna. Berdasarkan hasil penelitian tersebut, didapatkan empat aspek utama yang menggambarkan kesiapan kerja individu, yaitu:

\section{(1) Personal characteristics}

Karakteristik personal individu mengukur bagaimana daya lenting (resiliensi) dari individu, kemampuan untuk menyesuaikan diri di lingkungan kerja dan berbagai upaya pengembangan diri yang telah dilakukan. Aspek ini juga menggambarkan kemampuan personal, kemampuan untuk mengarahkan diri, pengenalan diri dan fleksibilitas.

\section{(2) Organisational acumen}

Aspek ini mengukur motivasi untuk bekerja di organisasi atau institusi tertentu, kesadaran mengenai organisasi atau institusi di tempat kerja yang dituju, perkembangan personal dalam perusahaan atau keinginan untuk mempelajari hal baru dan sikap positif atau negatif terhadap pekerjaan. Aspek ini juga mengukur profesionalisme dan etika dalam bekerja, tanggung jawab sosial, dan pengetahuan umum.

\section{(3) Work competence}

Aspek kompetensi pekerjaan merupakan aspek yang menggambarkan kemampuan teknis individu (spesifik pada pekerjaan yang akan dituju), motivasi dalam menyelesaikan tugas dan kemampuan menyelesaikan masalah. Aspek ini juga menggambarkan kemampuan organisasional individu, berpikir kritis, kemampuan menyelesaikan masalah, dan kreativitas.

\section{(4) Social intelligence}

Aspek ini menggambarkan orientasi interpersonal, kemampuan bekerja dan kolaborasi dalam kelompok/tim, keterampilan sosial/interpersonal dan kemampuan komunikasi.

Aspek-aspek tersebut menggambarkan berbagai dimensi dari kesiapan kerja. Individu bisa saja unggul dalam salah satu aspek namun kurang menunjukkan kemampuan pada aspek lainnya. Oleh karena itu, kesiapan kerja biasanya dianggap sebagai konsep yang multidimensi. Berbagai aspek kesiapan kerja tersebut akan diukur dengan menggunakan berbagai metode seperti: self report (dengan mengisi form aplikasi/lamaran kerja), tes kemampuan dan kepribadian serta wawancara. Hasil pengukuran tersebut kemudian diintegrasikan sehingga dapat dibuat kesimpulan yang cukup komprehensif.

Bagi seseorang yang baru lulus SMK, mencari pekerjaan dapat menjadi salah satu pengalaman yang menantang. Minimnya pengalaman kerja serta tidak adanya pengetahuan tentang seperti apa pencarian kerja itu dapat menjadikan para lulusan baru ini tidak mampu bersaing hingga putus asa dalam mencari kerja. Di antara yang jamak diketahui, dalam proses mencari kerja, pembuatan CV (Curriculum Vitae) dan kesiapan menghadapi wawancara dan psikotes merupakan salah satu proses dalam memasuki dunia kerja.

Di dunia kerja, tahap screening CV merupakan salah satu proses seleksi kerja paling awal yang dilakukan oleh HR/personalia sebuah perusahaan. Sebagian besar pencari kerja gagal untuk menarik perhatian $\mathrm{HR}$ /personalia pada proses awal ini sehingga tidak bisa melanjutkan ke jenjang 
seleksi selanjutnya. Sehingga diperlukan pengetahuan yang baik dalam menyusun CV agar potensi para lulusan baru ini dapat terlihat maksimal di mata para HR. Selain itu, proses psikotes dan wawancara juga salah satu tantangan tersendiri bagi para lulusan baru mengingat hal tersebut tidak diajarkan dalam pendidikan mereka. Padahal, dalam proses asesmen pencarian kerja, kedua hal ini termasuk yang paling sering dilakukan oleh perusahaan untuk menyeleksi pelamar kerja mereka. Para lulusan baru yang ingin mencari pekerjaan seringnya hanya fokus pada kemampuan umum yang diperlukan oleh perusahaan, tidak pada kemampuan spesifik yang sesuai dengan pekerjaan yang akan mereka lakukan. Selain itu, mereka juga tidak terbiasa dan tidak siap untuk menjelaskan secara lisan mengenai pengetahuan, keterampilan dan pengalamannya untuk menggambarkan potensi kemampuan yang dimiliki (Caballero \& Walker, 2010).

Oleh karena itu, siswa SMK yang akan masuk ke dunia kerja memerlukan pengetahuan spesifik terkait pekerjaan apa yang akan mereka lakukan. Hal ini diperlukan agar mereka dapat mempersiapkan diri untuk menghadapi proses rekrutmen yang nantinya menentukan apakah mereka akan mendapatkan pekerjaan tersebut atau tidak.

\section{Metode}

\section{Bentuk dan Tahapan}

Metode kegiatan yang digunakan adalah penyuluhan/pemberian informasi mengenai dua jenis proses seleksi dalam pencarian kerja: pembuatan CV yang dapat menarik minat HR dan proses psikotes. Kegiatan dilakukan dengan metode yang menarik seperti dengan menampilkan studi kasus, sharing pengalaman dan sebagainya. Pemilihan tempat dijatuhkan pada SMKN 39 Jakarta karena telah ada nota kesepahaman sebelumnya dengan Fakultas Psikologi YARSI selaku penyelenggara kegiatan.

Sebelumnya, pihak sekolah sudah mengupayakan beberapa cara untuk membantu mempersiapkan siswa seperti dengan mengadakan kegiatan magang/praktik kerja lapangan pada kegiatan yang sesuai jurusan, mengadakan pelatihan untuk persiapan memasuki dunia kerja. Materi yang disampaikan pada saat pelatihan umumnya terkait dengan cara membuat lamaran dan tips menghadapi proses seleksi kerja (psikotes dan wawancara). Berdasarkan hasil evaluasi kegiatan yang sudah dilakukan mandiri oleh sekolah pun, siswa merasakan manfaat dari kegiatan tersebut namun kurang memahami materi mengenai psikotes dan wawancara kerja. Oleh karena itu, guru Bimbingan Konseling selaku mitra kegiatan pengabdian masyarakat ini menyampaikan bahwa siswa membutuhkan materi lebih mengenai persiapan memasuki dunia kerja terutama mengenai persiapan menghadapi psikotes dan wawancara yang merupakan expertise dari para tim pengabdian masyarakat.

Kegiatan pertama adalah sosialisasi pencarian kerja bagi lulusan SMK. Setelah itu, peserta akan diberikan penjelasan mengenai bagaimana memilih pekerjaan, memilah pekerjaan yang asli dan palsu serta membuat CV. Setelah mendapatkan gambaran umum mengenai bagaimana mencari kerja dan menyiapkan berkas-berkas lamaran pekerjaan, materi akan fokus pada persiapan menghadapi psikotes dan wawancara. Pada sesi ini, akan dijelaskan mengenai hal-hal yang diukur pada saat psikotes dan wawancara serta tips dan trik dalam menghadapi kedua proses tersebut. Pada penjelasan proses wawancara, akan dilakukan simulasi di depan kelas agar siswa lebih mendapatkan gambaran mengenai proses tersebut. 


\section{Waktu Pelaksanaan}

Kegiatan pengabdian masyarakat telah dilaksanakan melalui Zoom Meeting pada tanggal 6 Agustus 2020 (Gambar 1). Kegiatan berlangsung dari pukul 10.00 WIB hingga pukul 12.30 WIB. Dalam pelaksanaan kegiatan, sarana dan alat yang digunakan adalah handphone masing-masing peserta dan laptop untuk presentasi materi. Alat-alat tersebut telah disediakan oleh pihak sekolah. Selain itu, setiap peserta juga mendapatkan modul pelatihan secara online. Evaluasi kegiatan dilakukan dengan dua cara: perubahan pengetahuan peserta mengenai pembuatan $\mathrm{CV}$, psikotes dan wawancara antara sebelum dan setelah pelaksanaan kegiatan serta evaluasi terhadap pelaksanaan kegiatan yang sudah dilakukan.
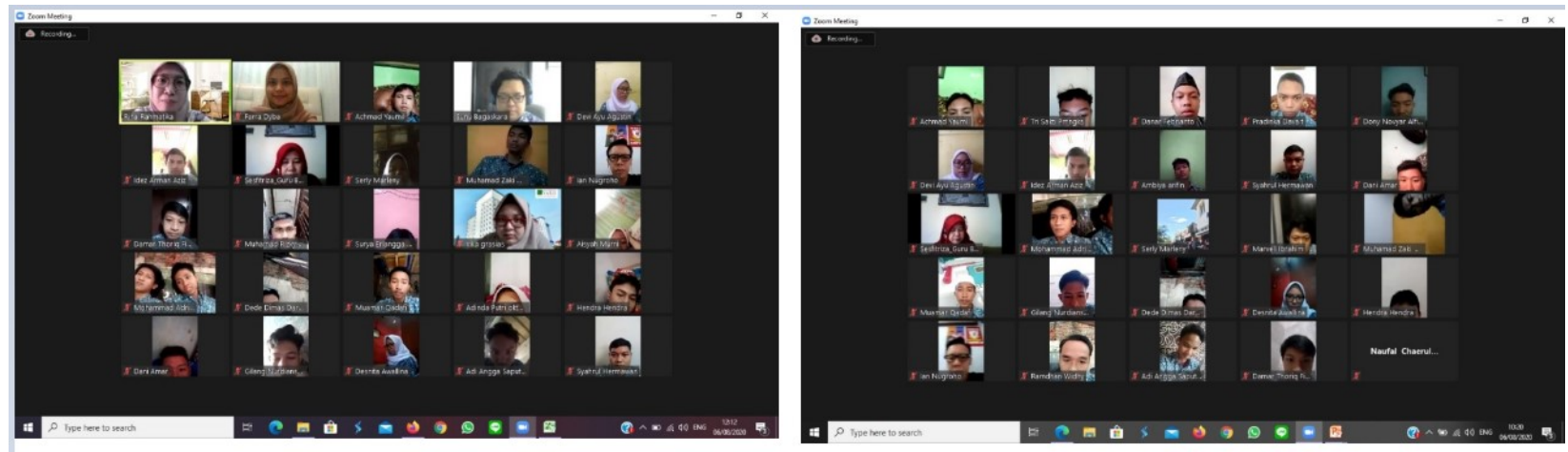

Gambar 1. Suasana pelaksanaan kegiatan melalui platform Zoom Meeting

\section{Hasil dan Pembahasan}

Kegiatan pelatihan yang dilakukan berjalan dengan lancar dan tidak ada kendala berarti. Pihak sekolah selaku mitra dalam kegiatan ini, sangat mendukung pelaksanaan kegiatan. Kegiatan rencananya akan diikuti oleh 30 peserta yang terdiri atas siswa dan guru BK. Akan tetapi, pada pelaksanaannya, kegiatan ini dihadiri oleh 27 siswa dan 2 orang guru BK di SMKN 39 Jakarta. Peserta pelatihan telah ditunjuk oleh guru BK yaitu mereka yang akan bersiap untuk magang. Selama pelaksanaan, siswa terlihat memperhatikan dan cukup aktif dalam sesi diskusi. Beberapa siswa juga aktif bertanya mengenai materi yang tidak mereka pahami.

Untuk mengevaluasi pengetahuan peserta, diberikan 10 soal sebelum (pretest) dan sesudah (posttest) diberikan materi. Soal-soal yang diberikan berkaitan dengan materi yang dipaparkan (contoh soal: “apa yang harus dipaparkan pada resume CV?"). Hasil pretetst dan posttest kemudian akan dibandingkan dengan menggunakan analisis $t$-test untuk memastikan jika ada peningkatan pengetahuan dari partisipan sebelum dan sesudah penyampaian paparan materi. Efektivitas kegiatan diukur dengan membandingkan pengetahuan peserta terkait materi sebelum dan sesudah acara. Peserta diberikan 10 pertanyaan pilihan ganda dengan nilai maksimal 10 untuk seluruh jawaban benar. Dalam Tabel 1 dan Tabel 2 berikut ini diketahui hasil uji beda skor kemampuan peserta antara sebelum dan setelah mengikuti kegiatan. 
Persiapan Dunia Kerja bagi Siswa SMKN 39 Jakarta: Edukasi Penulisan CV, Psikotes, dan Wawancara Rina Rahmatika, Novika Grasiaswaty, \& Sunu Bagaskara

\section{Evaluasi Pengetahuan Peserta}

Tabel 1 Deskripsi Statistik Pre-Test \& Post-Test

\begin{tabular}{c|cc}
\multicolumn{1}{c}{} & Pre-Test & Post-Test \\
\hline Jumlah subjek & 27 & 27 \\
Skor Tertinggi (Max) & 70,00 & 100,00 \\
Skor Terendah (Min) & 0,00 & 30,00 \\
Rata-rata (Mean) & 40,00 & 68,89 \\
Standar Deviasi & 15.93 & 18.26
\end{tabular}

Tabel 2 Hasil Paired Sample T-Test

\begin{tabular}{|c|c|c|c|c|c|}
\hline & Mean & $n$ & $t$ & $\begin{array}{c}\text { Mean } \\
\text { Difference }\end{array}$ & Sig. \\
\hline Pre-Test & 40,00 & 27 & 11,72 & 15,93 & 0,01 \\
\hline $\begin{array}{r}\text { Post- } \\
\text { Test }\end{array}$ & 68,98 & 27 & & & \\
\hline
\end{tabular}

Keterangan: Sig $(p<0.05)$

Tabel 1. menunjukkan bahwa pengetahuan peserta pelatihan mengenai informasi kesiapan kerja diukur secara berulang sebanyak dua kali. Pengukuran pertama dilakukan sebelum pelatihan dimulai. Pada pengukuran awal ini nilai rata-rata peserta adalah 40,00 $(\mathrm{SD}=15,93)$, dengan skor terendah 0,00 dan skor tertinggi 70,00. Angka ini menunjukkan bahwa secara umum pemahaman peserta sebelum pelatihan berada di bawah nilai tengah (50). Pengukuran kedua yang dilakukan setelah pelatihan diberikan menunjukkan peningkatan pemahaman peserta. Hal ini terlihat dari rata-rata skor yang mencapai $68,89(\mathrm{SD}=18,26)$, dengan nilai terendah adalah 30,00 dan tertinggi adalah 100,00. Dengan kata lain, terdapat peningkatan sebesar 28,89 poin antara sebelum dan setelah peserta mengikuti pelatihan. Analisis statistik paired samples t-test dilakukan untuk menguji signifikansi dari peningkatan tersebut. Hasil analisis pada Tabel 2. menunjukkan bahwa terjadi peningkatan skor rata-rata yang signifikan, $\mathrm{t}(26)=11,72, p<0,01$. Dari hasil analisis ini dapat disimpulkan bahwa pemahaman peserta mengenai kesiapan memasuki dunia kerja mengalami peningkatan yang berarti setelah mengikuti pelatihan. Dengan kata lain, pelatihan yang diberikan efektif untuk mempersiapkan peserta dalam memasuki dunia kerja.

Melalui pelatihan yang telah dilaksanakan, siswa SMK terbantu untuk memperoleh informasi yang terkait dengan persiapan yang dibutuhkan pada saat mencari pekerjaan. Peningkatan mengenai informasi kesiapan kerja yang terjadi menunjukkan bahwa melalui pelatihan kesiapan kerja dengan pemberian materi pembuatan $\mathrm{CV}$, psikotes dan wawancara menjadikan hal tersebut menjadi gambaran bagi peserta pelatihan yang akan mereka hadapi ketika mencari pekerjaan. Pemahaman yang diperoleh oleh siswa SMK mengenai pembuatan CV, psikotes dan wawancara membantu meningkatkan kesiapan kerja siswa SMK tersebut. Selain itu, diberikannya materi mengenai pembuatan $\mathrm{CV}$, psikotes, dan wawancara membantu mereka untuk 
meningkatkan soft skill sehingga membantu siswa SMK tersebut untuk bersiap dalam proses pencarian kerja. Hal ini pun sesuai dengan penelitian terdahulu yang ditemukan bahwa penguasaan soft skill berpengaruh terhadap kesiapan kerja seseorang (Afriani \& Setiyani, 2015). Berdasarkan hal tersebut, pelatihan mengenai persiapan kerja dengan memberikan materi mengenai cara membuat $\mathrm{CV}$, psikotes, dan wawancara mampu meningkatkan persiapan kerja siswa di SMKN 39 Jakarta.

\section{Evaluasi Pelaksanaan Kegiatan}

Selain melihat perbedaan nilai test pengetahuan peserta sebelum dan sesudah kegiatan, evaluasi juga dilakukan pada pelaksanaan kegiatan dengan menanyakan kepada peserta beberapa poin yang terkait dengan penyampaian materi. Dari Skala 4 Likert (Gambar 2), diketahui para siswa merasa jika kegiatan ini sangat bermanfaat (skor 3,78), dan materi yang diberikan telah jelas (skor 3,67). Sedangkan sikap pemateri telah dianggap baik (skor 3.52) dan metode kegiatan pun dianggap cukup tepat (skor 3.5). Selain secara kuantitatif, evaluasi juga dilaksanakan dengan kualitatf. Dari jawaban-jawaban para peserta, diketahui jika mereka merasa pemateri dianggap terlalu cepat dalam menyampaikan, serta usulan untuk melakukan permainan dan video yang menarik agar mereka lebih mudah memahami materi yang diberikan.

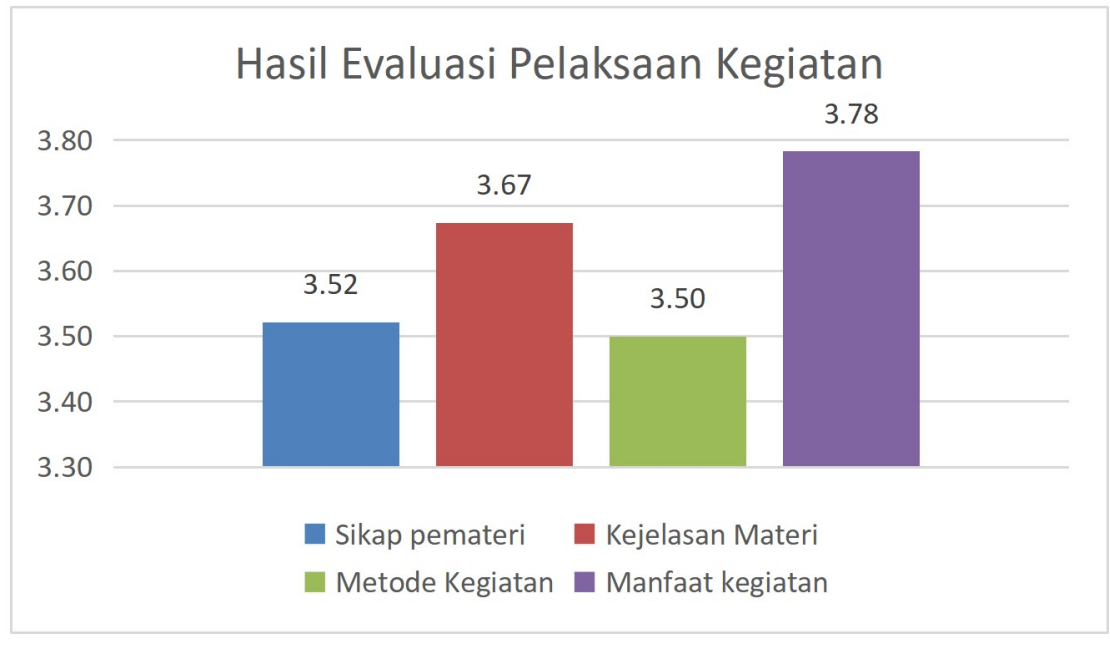

Gambar 2. Hasil Evaluasi Kegiatan

\section{Kesimpulan dan Saran}

Berdasarkan hasil evaluasi yang telah dilakukan, dapat diketahui bahwa kegiatan yang dilakukan efektif dalam mempersiapkan peserta memasuki dunia kerja. Adapun beberapa saran yang dapat diberikan terkait pelaksanaan pengabdian masyarakat ini adalah:

(1) Mengadakan kegiatan dengan tema yang serupa namun pada populasi yang berbeda, seperti siswa SMK sekolah lain atau guru BK yang tergabung dalam MGBK.

(2) Melakukan pengembangan kegiatan pelatihan dengan tema persiapan memasuki dunia kerja. Jika dikaitkan dengan hasil evaluasi, siswa mengharapkan adanya materi mengenai peningkatan kepercayaan diri untuk melamar kerja serta pendalaman dalam proses wawancara kerja. 
(3) Meskipun dilaksanakan secara online, kegiatan pengabdian masyarakat baiknya tetap menggunakan games atau hal-hal menarik agar peserta tidak cepat bosan.

\section{Pernyataan}

Tim penulis mengucapkan terima kasih kepada Universitas YARSI yang telah memberi dukungan finansial terhadap pengabdian ini melalui mekanisme Hibah Internal Pengabdian Masyarakat YARSI 2019.

\section{Referensi}

Afriani, R., \& Setiyani, R. (2015). Pengaruh Persepsi Siswa Tentang Kompetensi Kejuruan, Penguasaan Soft Skill, dan Kematangan Karir Terhadap Kesiapan Kerja Siswa Kelas XII Akuntansi SMK Negeri 2 Magelang Tahun Ajaran 2014/2015. Economic Education Analysis Journal, $\quad 4(2), \quad 453-468$. https://journal.unnes.ac.id/sju/index.php/eeaj/article/view/6776

Caballero, C. L., \& Walker, A. (2010). Work readiness in graduate recruitment and selection: A review of current assessment methods. Journal of Teaching and Learning for Graduate Employability, 1(1), 13-25. https://doi.org/10.21153/jtlge2010vollnolart546

Caballero, C. L., Walker, A., \& Fuller-Tyszkiewicz, M. (2011). The Work Readiness Scale (WRS): Developing a measure to assess work readiness in college graduates. Journal of Teaching and Learning for Graduate Employability, 2(2), 41-5441. https://doi.org/10.21153/jtlge2011vol2no1art552

Dharmawati, D. (2020). Pembelajaran Berbasis Komputer Menggunakan Ms. Office 2019 Pada Siswa Di Smk Dwitunggal 1 Tanjung Morawa. Dinamisia: Jurnal Pengabdian Kepada Masyarakat, 4(1). https://doi.org/10.31849/dinamisia.v4i1.3751

Firdaus, Z. Z. (2013). Pengaruh unit produksi, pengalaman prakerin dan dukungan keluarga terhadap kesiapan kerja siswa SMK. Jurnal Pendidikan Vokasi, 2(3), 397-409. https://doi.org/10.21831/jpv.v2i3.1045

Guntoro, G., Costaner, L., \& Sutejo, S. (2017). Pelatihan Sistem Pembelajaran E-Learning Pada Sekolah Menengah Kejuruan Dwi Sejahtera Pekanbaru. In Dinamisia : Jurnal Pengabdian Kepada Masyarakat (Vol. 1, Issue 1, pp. 39-45). https://doi.org/10.31849/dinamisia.v1i1.411

Juwitaningrum, I. (2013). Program Bimbingan Karir untuk Meningkatkan Kematangan Karir Siswa SMK. PSIKOPEDAGOGIA Jurnal Bimbingan Dan Konseling, 2(2), 132. https://doi.org/10.12928/psikopedagogia.v2i2.2580

Krisnamurti, T. F. (2017). Faktor-faktor yang Mempengaruhi Kesiapan Kerja Siswa SMK. Jurnal Pendidikan Dan Ekonomi, 6(1), 65-76. http://journal.student.uny.ac.id/ojs/index.php/ekonomi/article/view/6075

Kuswana, S. W. (2013). Dasar-dasar Pendidikan Vokasi \& Kejuruan. Alfabeta.

Lestari, I., \& Siswanto, B. T. (2015). Pengaruh pengalaman prakerin, hasil belajar produktif dan dukungan sosial terhadap kesiapan kerja siswa SMK. Jurnal Pendidikan Vokasi, 5(2), 183 194. https://doi.org/10.21831/jpv.v5i2.6384

Nuryanto, A., \& Eryandi, K. Y. (2020). The 21st Century Ideal Skills for Vocational High 
Amalee: Indonesian Journal of Communily Research and Engagement | Vol. 2 No. 2 (Jul 2021)

Schools. Proceedings of the International Conference on Educational Research and Innovation (ICERI 2019), 401(Iceri 2019), 142-147. https://doi.org/10.2991/assehr.k.200204.026 